Yüzüncü Y1l Üniversitesi
Tarim Bilimleri Dergisi

Araştırma Makalesi (Research Article)

Planning and Design of Prefabricated Beef Cattle Barns Constructed by Lightweight Concrete for Cold Climate Regions

\author{
Hasan ER ${ }^{* 1}$, Yasemin KUȘLU² \\ ${ }^{1}$ Bingöl Üniversitesi, Ziraat Fakültesi, Biyosistem Mühendisliği Bölümü, 12000, Bingol, Turkey \\ ${ }^{2}$ Atatürk Üniversitesi, Ziraat Fakültesi, Tarımsal Yapılar ve Sulama Bölümü, 25240, Erzurum, Turkey \\ ${ }^{1}$ https://orcid.org/0000-0002-7880-8697 ²https://orcid.org/0000-0003-4008-1004 \\ *Sorumlu yazar e-posta: hasaner@bingol.edu.tr
}

\section{Article Info}

Received: 11.11 .2019

Accepted: 19.01.2020

Online Published 31.03.2020

DOI: 10.29133/yyutbd.645396

\section{Keywords}

Tie-stall type,

Beef cattle barn,

Erzurum,

Lightweight concrete,

Prefabricated barn.

\begin{abstract}
It is very important to increase the income levels of livestock enterprises and engaged in animal production in our country by producing barns with modern and economic methods. In this study, prefabricated barn types which are built as opposed to traditionally built barns of the cold regions like Erzurum was revealed. Concerning tie-stall type barn, as for the number of animals 10, 20, and 30 headstocks discussed in the study. Moreover, the tie-stall prefabricated barn project is designed by using 50 tunnel type light-weight concrete materials to illustrate an example for commercial enterprises. At the end of the study, it was determined that prefabricated lightweight concrete barns were more economical than produced traditionally classical-type barns. As the number of cattle increased, the cost of barn decreased per cattle for cold climate conditions. The cost reduction percentage for 10-head barns was determined as $38.0 \%$ and $38.9 \%$ for lightweight concrete cylindrical roof and light concrete tunnel roofed barn types, respectively. These values were calculated as $60.5 \%$ $61.4 \%$ for 20 head barns, and 59.9\% - 60.4\% for the 30 head barns. Among the studied barn types, it was found that the most economically suitable barn combination was a prefabricated barn with tunnel roof and lightweight concrete.
\end{abstract}

\title{
Soğuk İklim Bölgelerine Uygun Hafif Beton ile Yapılan Prefabrik Sığır Ahırlarının Planlanması ve Tasarımı
}

\section{Makale Bilgileri}

Geliş: 11.11 .2019

Kabul: 19.01.2020

Online Yayinlanma 31.03.2020

DOI: $10.29133 /$ yyutbd.645396

\section{Anahtar kelimeler}

Bağlı duraklı tip, Besi sığırı ahırı, Erzurum,

Hafif beton,

Prefabrik ahır.
Öz: Ülkemizde hayvansal üretimin ve hayvancılıkla uğraşan işletmelerin gelir seviyelerinin artırılmasında, modern ve ekonomik yöntemler ile gerçekleşen hayvan barınaklarının inşa edilmesi çok önemlidir. Çalışmada Erzurum ve benzeri soğuk iklim koşullarına sahip bölgelerde, geleneksel üretim yöntemiyle inşa edilen besi ahırlarına seçenek olarak kullanılabilecek prefabrik ahır tipleri ortaya konulmuştur. Ahır tipi olarak bağlı duraklı, hayvan sayısı olarak 10, 20 ve 30 baş araştırmaya konu edilmiştir. Ayrıca ticari işletmelere örnek olması açısından 50 başlık tünel tipi hafif beton malzeme kullanılarak üretilebilecek bağlı duraklı prefabrik bir ahır projesi de tasarlanmıştır. Çalışmanın sonunda, prefabrik hafif beton ahırların geleneksel tip klasik ahırlardan daha ekonomik olduğu tespit edilmiştir. Soğuk iklim koşulları için büyükbaş hayvan sayısı arttıkça, hayvan başına ahır maliyeti azalmıştır. Maliyet azaltma oranı, 10 başlı ahırlar için hafif beton silindirik çatı ve hafif beton tünel çatılı ahır tiplerinde sırasıyla\% 38,0 ve \% 38,9 olarak belirlenmiştir. Bu değerler 20 baş ahır için\% 60,5 -\% 61,4, 30 baş ahır için\% 59,9 -\% 60,4 olarak hesaplanmıştır. İncelenen ahır tipleri arasında, ekonomik olarak en uygun ahır kombinasyonunun tünel çatılı ve hafif betonlu bir prefabrik ahır olduğu tespit edilmiştir. 


\section{Introduction}

Despite the development of technology and industry in the world, livestock maintains its importance for countries. The construction of shelters with suitable environmental conditions to meet the basic food and meat needs is an infrastructure cost that has a large share in livestock enterprises.

The purpose of animal shelters in livestock enterprises is to eliminate the negative impact on animals, to realize the most suitable production environment and to provide an environment suitable for the behavior of animals (Kizildag, 2012). The health status and yields of animals have a close relationship with the environmental conditions of the shelter. Therefore, the structural features of the shelters should be at an optimum level to obtain the most efficiency from the animals (Aydin et al., 2016).

The Eastern Anatolia Region of Turkey displays a structure on livestock in terms of the sectoral distribution of rural employment. The Eastern Anatolia Region has $26.8 \%$ of the total size and cattle of Turkey, and the region is noteworthy for the presence of cattle. Most of the population is engaged in livestock. 64\% of the agricultural economy of Erzurum Province consists of livestock. According to Turkish Statistical Institute (TUIK) 2017 data, the number of cattle in our country was 15943586 heads. The number of cattle in Erzurum province is 731828 heads. Erzurum, Turkey is the second province in the presence of cattle in the rankings. Erzurum is the third province in terms of the amount of milk obtained from cattle. Due to the geographical and climatic characteristics of the province and the large meadow pastures, the province has encouraged people living in the province to livestock. The most important problem is the low yield from animals and the animal needs of unsuitable animal shelters. Considering a new approach in terms of cost and labor force in Erzurum province, lightweight concrete prefabricated barns could be as an alternative to the traditionally constructed barns.

Lightweight concrete is defined as concrete produced with a unit weight less than $2200 \mathrm{~kg} /$ m3 using aggregates that are lighter than normal aggregate (TSE, 2002). Lightweight concrete produced by lightweight aggregate has superiority compared to normal concrete. These can be listed as; having lower unit weight, high sound and heat insulation properties, resistance to fire, ease of transportation and installation, less scale and less material due to shrinkage of the sections (Kocaman, 2000). Thermal expansion coefficient ( $\alpha \mathrm{t}$ ) of lightweight concrete is approximately $80 \%$ of normal concrete depending on aggregate type and quantity. In addition, lightweight concrete ranges from $8 \times 10^{-6} \sim 10 \times 10^{-6}\left(\mathrm{~m} / \mathrm{m}^{\circ} \mathrm{C}\right)$ (Tasdemir, 2003).

Concretes with a specific weight not exceeding $1840 \mathrm{~kg} \mathrm{~m}^{-3}$ and a compressive strength of 28 days exceeding $17 \mathrm{MPa}$ are classified as lightweight concrete. According to the standards of the countries, the specific weight of light concrete is allowed to increase up to $1900 \mathrm{~kg} / \mathrm{m}^{3}$.

Table 1. Lightweight Concrete Grade (Tasdemir, 2003).

\begin{tabular}{ccc}
\hline Lightweight Concrete Grade & Specific weight $\left(\mathrm{kg} \mathrm{m}^{-3}\right)$ & Compressive strength $(\mathrm{MPa})$ \\
\hline S1 & 800 & $1-7$ \\
S2 & $800-1200$ & $7-10$ \\
S3 & $1000-1400$ & $10-14$ \\
S4 & $1300-1800$ & $14-25$ \\
S5 & $1500-1800$ & $25-40$ \\
S6 & $1800-2000$ & $40-70$ \\
\hline
\end{tabular}

It is also possible to classify lightweight concrete as in Table 1. S1 class concrete is used to provide thermal insulation. S2 and S3 concretes are medium-strength concretes and have insulation properties. S4, S5 and S6 concretes are lightweight concrete. They are considered as carrier concrete in many countries.

Environmental conditions in the stable should be brought to appropriate levels to prevent cattle from being exposed to adverse environmental conditions and to increase production (Cook et al., 2007). To ensure adequate ventilation in the barns, if the number of animals is up to 50 head, it is stated that the barn height should be 3-3.75 m. At least one ventilation chimney must be calculated for the $100 \mathrm{~m}^{2}$ barn floor area. Stall cubicle varies according to the age, type, and weight of cattle. Stall cubicle length should be $240-270 \mathrm{~cm}$ and $120 \mathrm{~cm}$ for large breeds. The length should be $230 \mathrm{~cm}$ and the width should be $110 \mathrm{~cm}$ for small-scale breeds (Sahanoglu and Kocak, 2014; Anonymous, 2013). 
The barn floor must be covered with materials that prevent the animals from slipping. The drainage and scraper systems must be good for the manure and animal cleaning in the barn (Önes and Olgun, 1989; Akman, 2012). Feed space length for the cattle should be 65-75 cm. 45-70 cm waterer length for cattle is stated to be sufficient capacity. Waterers are usually placed in navigation areas. One waterer is sufficient for 15 cattle. (Yüksel, 1984; Sahanoglu, 2014).

It is stated that 100 Watt light source will be sufficient for $40-50 \mathrm{~m}^{2}$ barn areas in areas where natural lighting is insufficient and artificial lighting is used. The appropriate temperature limit for the cattle is between $-18^{\circ} \mathrm{C}$ and $+24^{\circ} \mathrm{C}$ (Yaganoglu, 1986; Kadzere et al., 2002). It is argued that the appropriate moisture level should be between 50-75\% (İcöz, 1998). Heat insulation operations are applied to prevent hot or cold air from entering or leaving the barn by creating heat bridges. Generally used in thermal insulation materials; glass wool, rock wool, Expanded Polystyrene insulation foam (EPS), Extruded polystyrene insulation foam (XPS), polyurethane foam (Ceylan, 2012).

In this study, a new approach in terms of cost and workforce in Erzurum province was taken into consideration and it was decided to carry out this research to contribute to the building material and construction method of animal shelters. In the study, 10, 20 and 30 head of prefabricated tie-stall beef cattle barn plans with light concrete material were developed considering the cold climatic conditions. In this way, it was aimed to increase the income level in the agricultural enterprises which are active in rural areas and to make a contribution to preventing uncontrolled migration from rural areas to urban areas.

\section{Materials and Methods}

Erzurum region was chosen as the research material region. The province of Erzurum is located between $40^{\circ}-15^{\prime}$ and $42^{\circ}-35^{\prime}$ east longitudes and $40^{\circ}-57^{\prime}$ and $39^{\circ}-10^{\prime}$ north latitudes in terms of geographic location. $64 \%$ of the total agricultural land in the province is meadow-pasture land. The agricultural land is 460252 hectares and the area of 305636 hectares is suitable for irrigation. The total population of the province is 762021 and 417385 of them live in central districts (TUIK, 2017).

The province of Erzurum, which is located in the continental climate zone, is mostly dry and hot in summers and generally cold and snowy in winters. The temperature difference between day and night is high. The average annual temperature is $5.7^{\circ} \mathrm{C}$. The coldest month is January with an average temperature of $-9.1^{\circ} \mathrm{C}$ and the hottest month is August with $19.5^{\circ} \mathrm{C}$. The average annual precipitation is $432.8 \mathrm{~mm}$, with the highest precipitation decreasing by $73.1 \mathrm{~mm}$ in May and the lowest precipitation with $17.5 \mathrm{~mm}$ in August. 52.39\% of the annual rainfall $(221.5 \mathrm{~mm})$ falls in the plant vegetation period, 1 May-20 October. In August, the relative humidity is determined as $47 \%$, the lowest in December and January, with the highest values of $76 \%$, with an average annual relative humidity of $64 \%$ (Anonymous, 2016).

Heat and moisture balance was considered in the design of the family-type beef cattle barns, design of building elements and design of ventilation systems and the principles given by Mutaf and Sönmez (1984), Balaban and Sen (1988), Bozkir (2001), Gürkan et al. (2005), Polat and Damci (2007), Uzal and Ugurlu (2008), Usta (2011) and Anonymous (2013), were taken into consideration. In the calculations, the temperature inside the barn for winter was $10^{\circ} \mathrm{C}$ and the relative humidity $80 \%$. Average low temperature and relative humidity values for the coldest month of the region were taken as the external temperature and relative humidity of the Project. In the calculations regarding the ventilation and summer ventilation, the principles are given in Ekmekyapar (2001) were taken into consideration. Ventilation openings were made based on the temperature balance and it was checked whether the values provided provide the moisture balance. The average weight of the cattle in the fattening barn is $500 \mathrm{~kg}$ (Ekmekyapar, 2001).

Prefabricated tie-stall barns with 10, 20 and 30 head family-type and 50 head commercial types were planned by using TS 9967 (1992), TS498 (1997), TS500 (2000) and TSE (2002) related to lightweight concrete prefabricated structures. 2018 cost calculations of the cattle barns were made and compared with the classical type tie-stall cost calculation calculated using the same year data. The cost calculations of these cattle barns were realized with the prices obtained from the construction unit exposure list of the Ministry of Environment and Urbanization and the companies in the market.

Formulas used in the study;

Assuming the average weight of the cattle in the beef barn as $500 \mathrm{~kg}$. 
The amount of water vapor emitted by a cattle is calculated by the following equation $(\mathrm{g} / \mathrm{h})$ :

$\mathrm{N}=\mathrm{A} * \mathrm{k} 1 * \mathrm{n}$

In Equation;

$\mathrm{k} 1=$ Amount of water vapor emitted from $1 \mathrm{~m}^{2}$ body surface area at $10^{\circ} \mathrm{C} \mathrm{g} / \mathrm{m}^{2} \mathrm{~h}$

$\mathrm{n}=$ the number of cattle in the barn.

In determining the amount of ventilation required

$\mathrm{Q}=\mathrm{A} \times \mathrm{V}$

Equation is used. In equation;

$\mathrm{Q}=$ ventilation capacity $\left(\mathrm{m}^{3} / \mathrm{h}\right)$

$\mathrm{A}=$ sum of air outlet openings $\left(\mathrm{m}^{2}\right)$

$\mathrm{V}=$ speed of air current is $(\mathrm{m} / \mathrm{s})$, it is decided upon the equation below

$\mathrm{V}=1,8 * \sqrt{ }((\mathrm{H}(\mathrm{ti}-\mathrm{td})) /(273+\mathrm{td}))$

In equation;

$\mathrm{H}=$ chimney effective height (m)

$\mathrm{ti}=$ interior temperature of barn ${ }^{\circ} \mathrm{C}$

$\mathrm{td}=$ barn outdoor temperature is ${ }^{\circ} \mathrm{C}$

Number of ventilation chimneys;

$\mathrm{n}=\mathrm{A} / \mathrm{a}$

is calculated with the equation above. In equation;

$\mathrm{A}=$ sum of air outlet openings $\left(\mathrm{m}^{2}\right)$

$\mathrm{a}=$ chimney area is $\left(\mathrm{m}^{2}\right)$

According to the Regulation on Minimum Conditions to be Adhered to within the Scope of Investment of the Agriculture and Rural Development Support Institution, the Window account is taken as $5 \%$ of the barn floor area. It has been checked whether the values calculated by equality meet this rule.

Equation 5 was used to determine the number of windows.

$\mathrm{p}=\mathrm{A} / \mathrm{a}$

In equation;

$\mathrm{A}=$ sum of window openings $\left(\mathrm{m}^{2}\right)$

$\mathrm{a}=$ window area is $\left(\mathrm{m}^{2}\right)$

\section{Results}

The cost calculations of 10, 20 and 30 head cylindrical and tunnel roof prefabricated beef cattle barns produced with lightweight concrete suitable for Erzurum province conditions were prepared. As an example for commercial enterprises, 50 head prefabricated barn were produced from lightweight concrete.

The dimensional calculations of 10, 20, 30 and 50 head prefabricated barns with lightweight concrete are given in Table 1.

Table 2. Dimensional calculations of prefabricated barns with beef cattle

\begin{tabular}{lllll}
\hline Acceptances and calculations & 10 head & 20 head & 30 head & 50 head \\
\hline Barn Height(m) & 4 & 4 & 4 & 4 \\
Barn Width $(\mathrm{m})$ & 7 & 7 & 10 & 10 \\
Barn Length $(\mathrm{m})$ & 18 & 30 & 824 & 37 \\
Amount of Ventilation $(\mathrm{kg} / \mathrm{h})$ & 949.45 & 1898.86 & 2848.2 & 3915.7 \\
Total Number of Windows (piece) & 5 & 8 & 8 & 12 \\
Total window area $\left(\mathrm{m}^{2}\right)$ & 6.3 & 10.5 & 12 & 14.4 \\
Number of ventilation chimneys & 2 & 3 & 5 & 8 \\
Special partition area $\left(\mathrm{m}^{2}\right)$ & 4.7 & 4.7 & 4.7 & 11.55 \\
Feed Storage Area $\left(\mathrm{m}^{2}\right)$ & 4.7 & 4.7 & 7.7 & 11.55 \\
\hline
\end{tabular}

Table 2 and Table 3 provide the calculation of the cost of the cylindrical and tunneled roofs of the prefabricated barn, which are produced with lightweight concrete, with the tie-stall. Also, the cost 
calculations for the 50 head prefabricated beef cattle barn with lightweight concrete, tunnel roof, and tie-stall, which could be an example for commercial enterprises, are given in Table 4.

Table 3. Prefabricated barn with a cylindrical roof made of lightweight concrete material

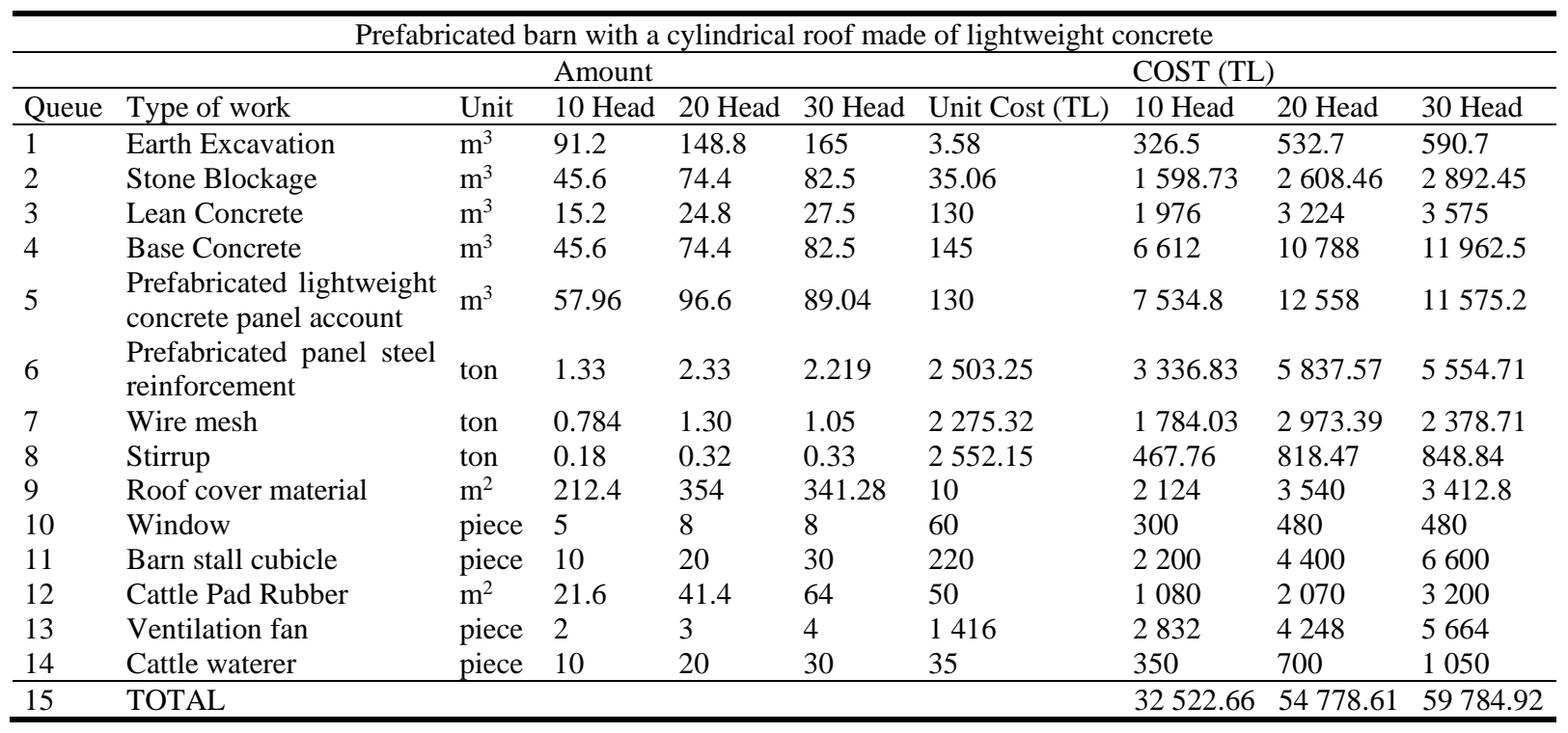

Table 4. Tunnel type prefabricated barn meter made with lightweight concrete material

\begin{tabular}{|c|c|c|c|c|c|c|c|c|c|}
\hline \multicolumn{10}{|c|}{ Barns with tunnel roofs made of lightweight concrete } \\
\hline & & & Amount & & & & COST (TL & & \\
\hline Queue & Type of work & Unit & 10 Head & 20 Head & 30 Head & Unit Cost & 10 Head & 20 Head & 30 Head \\
\hline 1 & Earth Excavation & $\mathrm{m}^{3}$ & 91.2 & 148.8 & 165 & 3.58 & 326.5 & 532.7 & 590.7 \\
\hline 2 & Stone Blockage & $\mathrm{m}^{3}$ & 45.6 & 74.4 & 82.5 & 35.06 & 1598.73 & 2608.46 & 2892.45 \\
\hline 3 & Lean Concrete & $\mathrm{m}^{3}$ & 15.2 & 24.8 & 27.5 & 130 & 1976 & 3224 & 3575 \\
\hline 4 & $\begin{array}{l}\text { Base Concrete } \\
\text { Prefabricated }\end{array}$ & $\mathrm{m}^{3}$ & 45.6 & 74,4 & 82.5 & 145 & 6612 & 10788 & 11962.5 \\
\hline 5 & $\begin{array}{l}\text { lightweight concrete } \\
\text { panel account }\end{array}$ & $\mathrm{m}^{3}$ & 53 & 88.31 & 88.69 & 130 & 6890 & 11480.3 & 11529.7 \\
\hline 6 & $\begin{array}{l}\text { Prefabricated panel } \\
\text { steel reinforcement }\end{array}$ & ton & 1.29 & 2.26 & 2.01 & 2503.25 & 3238.50 & 5667.35 & 5042.04 \\
\hline 7 & Wire mesh & ton & 0.76 & 1.26 & 1.01 & 2275.32 & 1731.51 & 2866.90 & 2308.54 \\
\hline 8 & Stirrup & ton & 0.19 & 0.33 & 0.30 & 2552.15 & 486.49 & 852.41 & 771.82 \\
\hline 9 & Roof cover material & $\mathrm{m}^{2}$ & 212.4 & 354 & 341.28 & 10 & 2124 & 3540 & 3412.8 \\
\hline 10 & Window & piece & 5 & 8 & 8 & 60 & 300 & 480 & 480 \\
\hline 11 & Barn stall cubicle & piece & 10 & 20 & 30 & 220 & 2200 & 4400 & 6600 \\
\hline 12 & Cattle Pad Rubber & $\mathrm{m}^{2}$ & 21.6 & 41.4 & 64 & 50 & 1080 & 2070 & 3200 \\
\hline 13 & Ventilation fan & piece & 2 & 3 & 4 & 1416 & 2832 & 4248 & 5664 \\
\hline 14 & Cattle waterer & piece & 10 & 20 & 30 & 35 & 350 & 700 & 1050 \\
\hline 15 & TOTAL & & & & & & 31745.75 & 53458.14 & 59079.56 \\
\hline
\end{tabular}


Table 5. 50 head with tunnel roof made of lightweight concrete material prefabricated barn

\begin{tabular}{|c|c|c|c|c|c|}
\hline Queue & Type of Work & Unit & Amount & Unit Cost & Cost (TL) \\
\hline 1 & Earth Excavation & $\mathrm{m}^{3}$ & 250.8 & 3.58 & 897.9 \\
\hline 2 & Stone Blockage & $\mathrm{m}^{3}$ & 125.4 & 35.06 & 4396.52 \\
\hline 3 & Lean Concrete & $\mathrm{m}^{3}$ & 41.8 & 130 & 5434 \\
\hline 4 & Base Concrete & $\mathrm{m}^{3}$ & 125.4 & 145 & 18183 \\
\hline 5 & $\begin{array}{l}\text { Prefabricated lightweight concrete panel } \\
\text { account }\end{array}$ & $\mathrm{m}^{3}$ & 137.27 & 130 & 17845.1 \\
\hline 6 & Prefabricated panel steel reinforcement & ton & 3.082 & 2503.25 & 7715.01 \\
\hline 7 & Wire mesh & ton & 1.54 & 2275.32 & 3522.19 \\
\hline 8 & Stirrup & ton & 0.42 & 2552.15 & 1081.70 \\
\hline 9 & Roof cover material & $\mathrm{m}^{2}$ & 526.14 & 10 & 5261.4 \\
\hline 10 & Window & piece & 12 & 60 & 720 \\
\hline 11 & Barn stall cubicle & piece & 50 & 220 & 11000 \\
\hline 12 & Cattle Pad Rubber & $\mathrm{m}^{2}$ & 108 & 50 & 5400 \\
\hline 13 & Ventilation fan & piece & 6 & 1416 & 8496 \\
\hline 14 & Cattle waterer & piece & 50 & 35 & 1750 \\
\hline 15 & TOTAL & & & & 91702.84 \\
\hline
\end{tabular}

For example, the floor plan and front view of 10-headed prefabricated barn with lightweight concrete is shown in Figures 1 and 2.

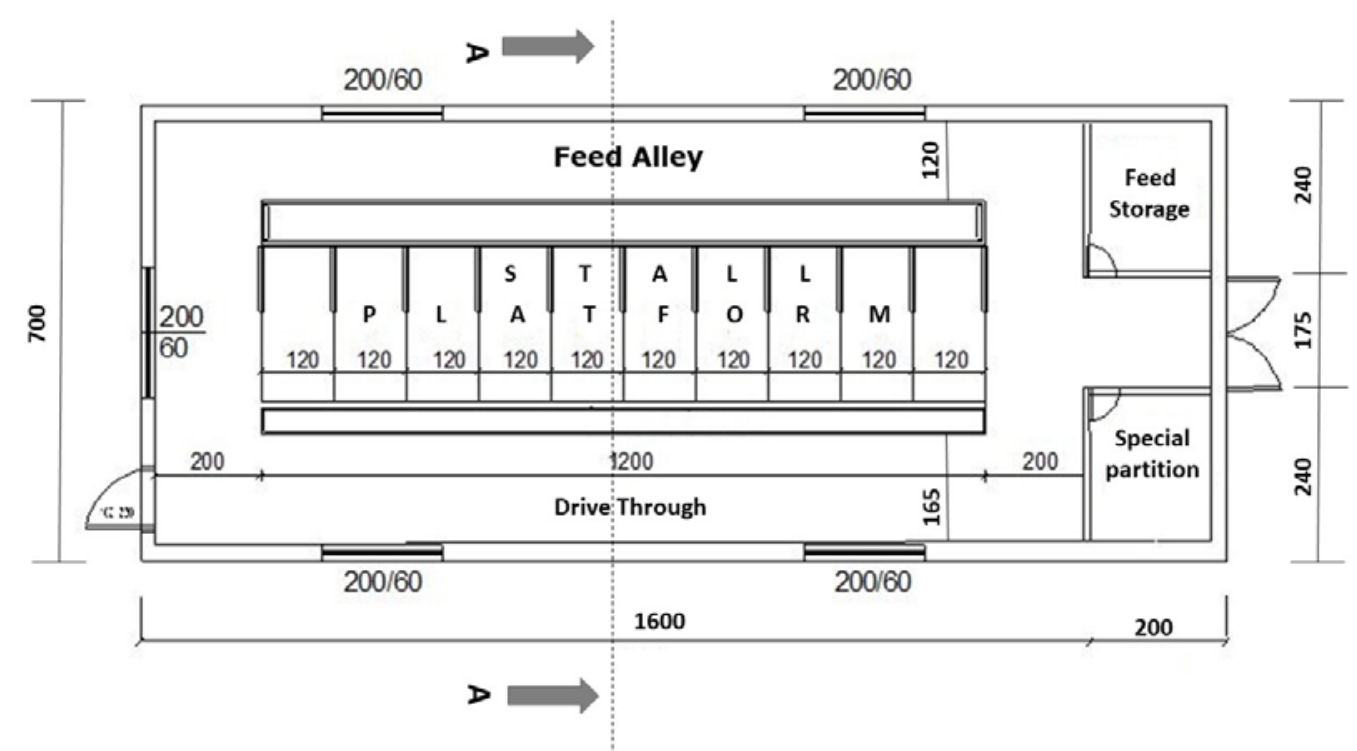

Figure 1. The floor plan of 10-headed prefabricated barn with lightweight concrete 


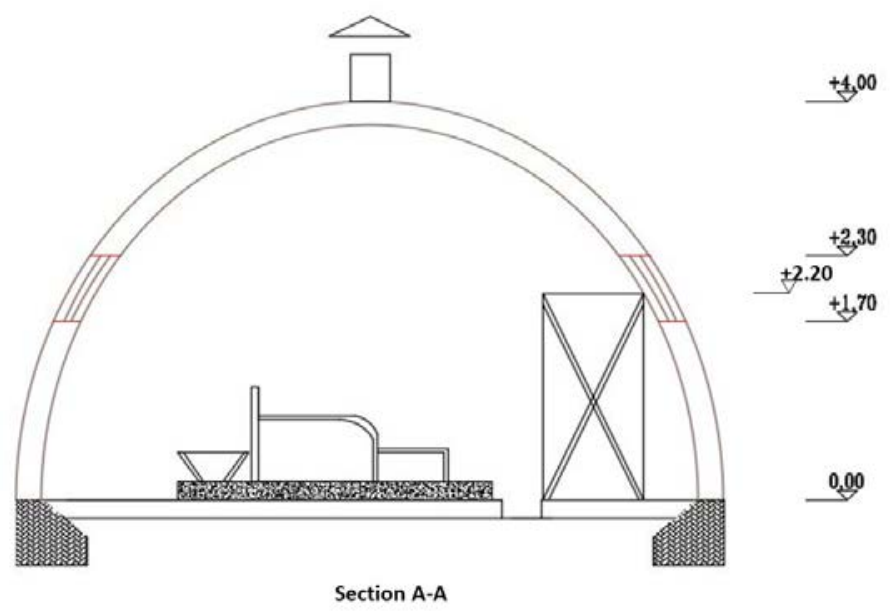

Figure 2. the sectional view of 10-headed prefabricated barn with lightweight concrete

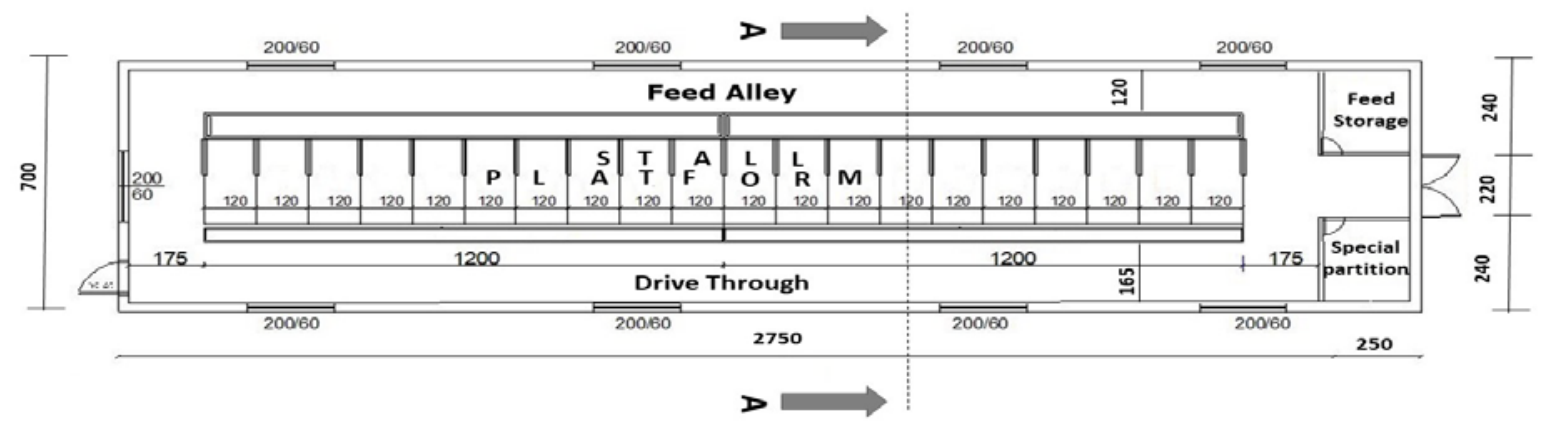

Figure 3. The floor plan of 20-headed prefabricated barn with lightweight concrete

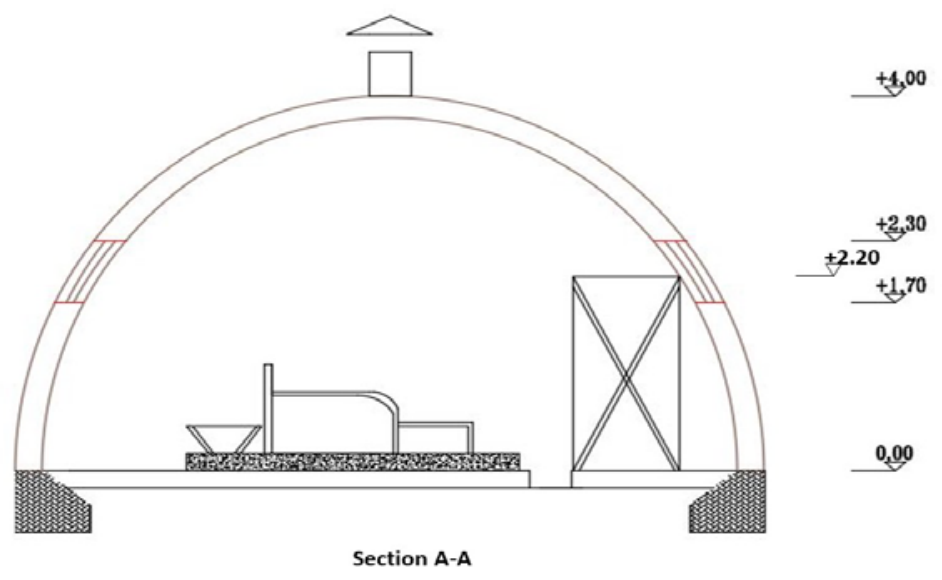

Figure 4. the sectional view of 20-headed prefabricated barn with lightweight concrete 


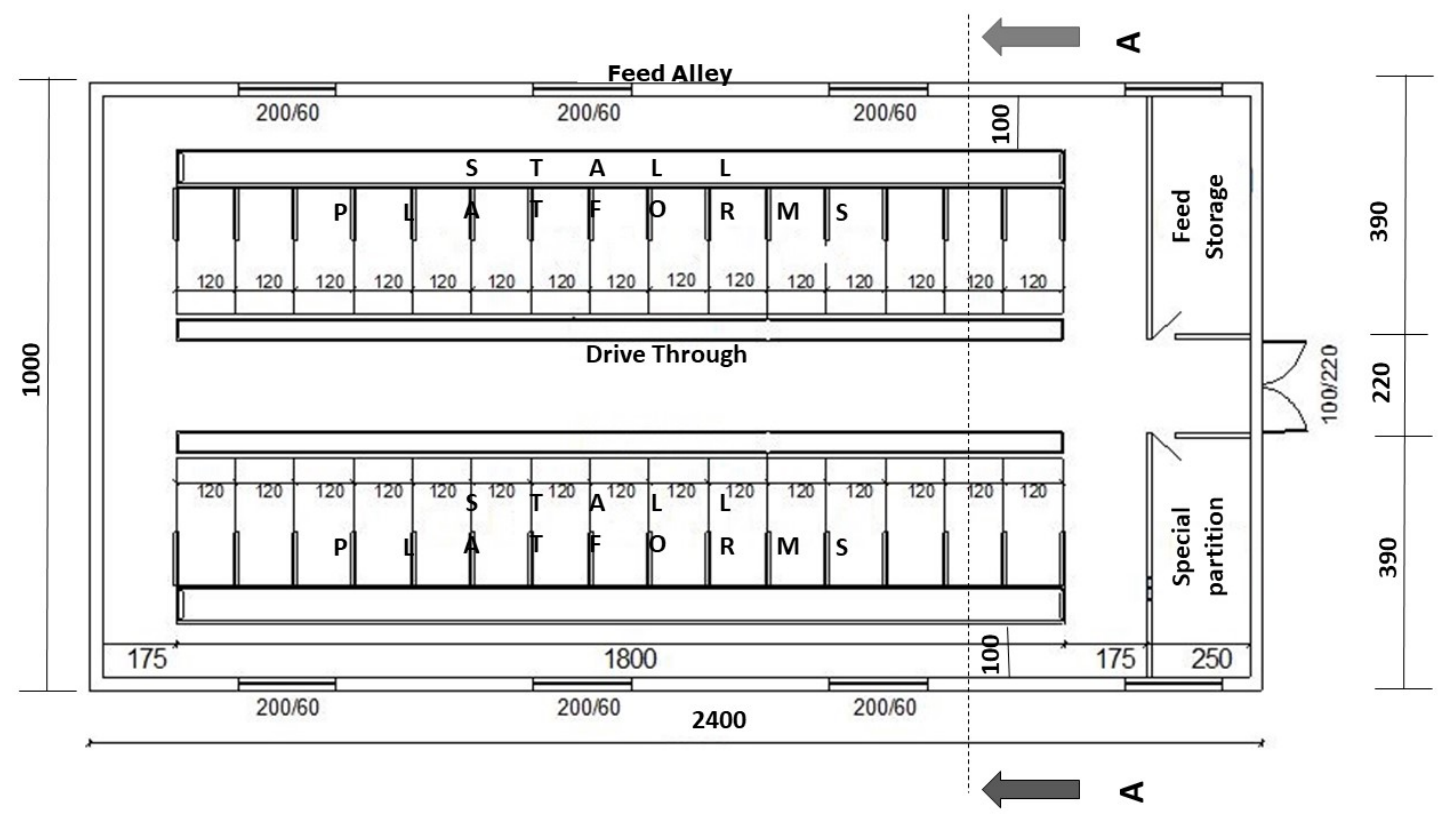

Figure 5. The floor plan of 30-headed prefabricated barn with lightweight concrete

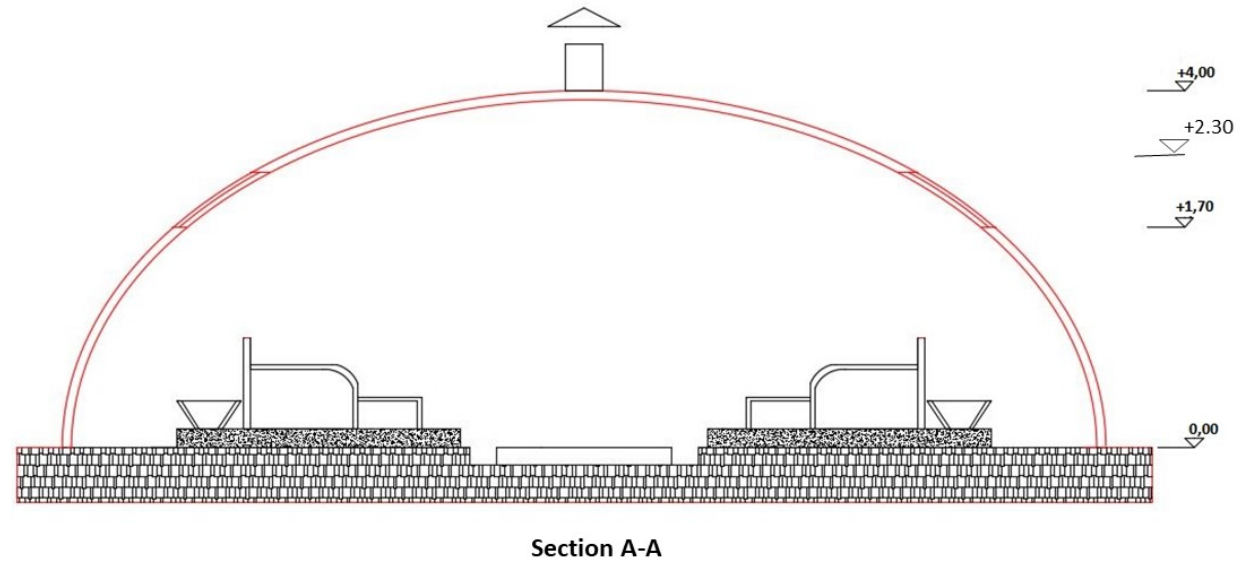

Figure 6. the sectional view of 20-headed prefabricated barn with lightweight concrete

Prefabricated barns are more economical in terms of 10 tie-stall beef cattle barn done with traditional methods as a result of comparing the cost per cattle with the cost of the prefabricated barn with the same characteristics. Cost reduction percentage was determined as $38.0 \%$ and $38.9 \%$ for lightweight concrete cylindrical roof and light concrete tunnel roofed barn types, respectively. Similarly; The cost of prefabricated barns per animal for beef cattle barn with 20 head was found to be lower than those built by the traditional method. The cost reduction percentage was $60.5 \%$ and $61.4 \%$ for lightweight concrete cylindrical roof and light concrete tunnel roofed barn types, respectively. The cost-reduction percentage values listed above were determined as $59.9 \%$ and $60.4 \%$ for the 30 -headed cattle barn. Taking these values into account, the most cost-effective barn type for prefabricated beef cattle barn with per unit animal; it is observed that there is a barn with a tunnel roof made of lightweight concrete material. 
Much of the work and research on lightweight concrete involves the elimination of negativity resulting from the high cost of fixed loads in traditionally produced structures. Low transportation costs due to the weight of concrete open the door to new economies related to lightweight concrete. As a result of the calculations and investigations carried out in this research, it has been observed that among the prefabricated cattle barn, the most suitable ones are those produced by lightweight concrete. Sabir (2016) emphasized that lightweight concrete is effective in reducing the carrier element dimensions compared to normal concrete, its strength is sufficient and it is a low-cost material. According to the information provided by the American Concrete Institute (ACI) (2003), the transportation costs of lightweight concrete are reported to be seven times less than in normal concrete. He emphasized that the transportation costs of prefabricated elements made of lightweight concrete, especially in small sizes, are the most economical.

\section{Discussion and Conclusion}

The planning of more economical structures with various materials should be considered by applying modern techniques to old type barns that cause diseases and cause a decrease in productivity.

In this study, cost calculations were made by making prefabricated barns with cylindrical and tunnel roofs produced with 10, 20 and 30 head lightweight concrete. Additionally, the cost of the classic barn was calculated and a comparison made. As a result of the cost calculations; Barns made of lightweight concrete are more economical than traditional type barns. This is because the unit price of lightweight concrete is low.

At the end of the study; Among the types of prefabricated barns, it was determined that the type of light concrete tunnel roofed barn was the most economical production. However, it can be said that prefabricated barn types are economically more suitable than traditional barn types under all conditions.

The use of prefabricated building elements in barn production is very important in areas with adverse climate conditions such as Erzurum, where the construction period is short in terms of shortening of construction times because it is produced in factories. When it is considered for the earthquake, complying with the production rules and making the installation with care, the strength and durability of the prefabricated structures must be sufficient. It is appropriate to use the lightweight concrete in the carrier and non-bearing structural elements due to the strengthening of the thermal insulation properties of the hollow structure and its strength.

\section{Acknowledgment}

This research was produced from the project supported by Atatürk University with code number FYL-2018-6565.

\section{References}

ACI Committee 213, (2003). Lightweight Concrete. 213R-03: Guide for Structural LightweightAggregate Concrete, pp.38.

Akman, N., (2012). Barınaklar. http://docplayer.biz.tr/9503138-Barinaklar-barinaklar-bolumu-a uziraat-fakultesi\%20zootekni-bolumu-ogretim-uyesi-prof-dr-numan-akman tarafindan \%20 hazirlanmistir. Html: erişim tarihi:16.02.201711:25.

Anonymous, (2013). Hayvancilıkta ahır planlaması. http://samsun.tarim.gov.tr/Belgeler/ Yayinlar/Lifletlerimiz/h-12.pdf erişim tarihi: 09/04/2017 00:18.

Anonymous, (2016). İllere ait mevsim normalleri. https://www.mgm.gov.tr/ veridegerlendirme/il-veilceler-istatistik.aspx?m=ERZURUM erişim tarihi: 08/08/2017 12:02.

Aydın, R., Güler, O., Yanar, M., Diler, A., Koçyiğit, R., \& Avcı, M. (2016). Socio-Economic structures of cattle enterprises in hinıs district of erzurum province, KSU J. Nat. Sci., 19(1), 37-42, Research Article, Erzurum.

Balaban, A., \& Şen, E., (1988). Tarımsal Yapılar. Ankara Üniversitesi Ziraat Fakültesi 
Bozkır, M., (2001). Hafif prefabrike sistemlerle afet sonrası acil konut üretiminde malzeme seçimi ve yapı fiziği sorunları. Mimar Sinan Üniversitesi, Fen Bilimleri Enstitüsü, Mimarlık Anabilim Dalı Yüksek Lisans Tezi, İstanbul.

Ceylan, N., (2012). Türkiye'de konut dış duvar sistemlerinde gerçekleştirilen isı yalıtımı uygulamalarının üretim ve yapım süreçlerinin çevresel değerlendirmesi. İstanbul Teknik Üniversitesi Fen Bilimleri Enstitüsü Mimarlık Anabilim Dalı Yüksek Lisans Tezi, İstanbul.

Cook, N. B., Mentink, R. L., Bennett, T. B. \& Burgi, K. (2007). The effect of heat stress and lameness on time budgets of lactating dairy cows. J. Dairy Sci. 90, 1674-1682.

Ekmekyapar, T., (2001). Hayvan Barınaklarında Çevre Koşullarının Düzenlenmesi. Atatürk Üniversitesi Ziraat Fakültesi Yayınları, Erzurum.

Gürkan, A. K., Gürdil, K., Selvi, Ç., Lüle, F., \& Yeşiloğlu, E., (2005). Developıng a software for determination of natural ventılation rate in animal houses, J. of Fac. of Agric., OMU, 20(1), 30-36.

Kadzere, C.T., Murphy, M.R., Silanikove, N. \& Maltz, E. (2002). Heat stress in lactating dairy cows: a review. Livestock Production Science 77, 59-91.

Kocaman, B., (2000). Doğu anadolu bölgesi’ndeki doğal hafif ve normal agregalarla üretilen betonların fiziksel, mekanik ve ıs iletkenlik özelliklerin belirlenmesi ile tarımsal yapılarda kullanılma olanakları üzerine bir araştırma. Atatürk Üniversitesi, Fen Bilimleri Enstitüsü, Tarımsal Yapılar ve Sulama Anabilim Dalı Doktora Tezi, Erzurum.

Mutaf, S., \& Sönmez, R., (1984). Hayvan Barmaklarında İklimsel ve Çevre Denetimi. Ege Üniversitesi Ziraat Fakültesi Yayınları, Yayın No: 438,258s. İzmir.

Öneş, A., \& Olgun M., (1989). Tarımsal Yapılarda Planlama ve Projelendirme Kriterleri. Bayındırlık ve İskan Bakanlığı Yayınları. Sayı: 104, Ankara.

Polat, G., \& Damc1, A., (2007). Türk inşaat sektöründe prefabrik betonarme yapı elemanlarının kullanımını etkileyen faktörler. http://www.imo.org.tr/resimler/ ekutuphane/pdf/1556.pdf (erişim tarihi: 18/05/2017 17:28).

Sabır, S. Q., (2016). Light weight concrete. http://keu92.org/uploads/Search\%20 engineering/Light\%20weight\%20concrete.pdf (erişim tarihi:05/07/2017 08:03).

Şahanoğlu, E., \& Koçak, S., (2014). Evaluation of animal welfare conditions in terms of barns and husbandry practices in dairy cattle enterprises of Afyonkarahisar province. Lalahan Hay. Araşt. Enst. Dergisi, 54, (2), 47-55.

Taşdemir, C., (2003). Hafif Betonların Isı Yalıtım ve Taşıyıcılık Özelikleri. Türkiye Mühendislik Haberleri, Sayı; 427-2003/5

TSE, (2002). Beton-Bölüm 1: Özellik, Performans, Imalat ve Uygunluk, TS EN 206-1, Türk Standartları Enstitüsü, Ankara.

Türkiye İstatistik Kurumu (TÜİK) (2017). Bölgesel göstergeler, Ankara.

Usta, S., (2011). Free stall dairy cattle farms architectural layout plan principles and suggestions for the nature of manufacturer type residential development plans. SDU Journal of Technical Sciences, 1, (2) 29-42.

Uzal S., \& Uğurlu N., (2008). The effect of climatic condition on area preference of animals in dairy cattle houses. J. Int. Environmental Application \& Science, 3 (4), 224-233.

Yağanoğlu, A. V., (1986). Hayvan barınaklarında çevre koşullarının düzenlenmesi. Dergi Park Akademik Ziraat Dergisi, 17, (1-4), 121-129.

Yüksel, A. N., (1984). Tarımsal Yapılar Ders Notları. Trakya Üni Zir. Fak. Yay. Edirne. 